\title{
A Common Concern of Humankind Approach to Monetary Stability
}

Monetary stability is indisputably a public good at the domestic level and an essential global public good (GPG) for the international community. Therefore, there are overlapping jurisdictions dealing with monetary stability at the different levels of governance. ${ }^{1}$ Notwithstanding that, since the collapse of the rule-based system of 'Bretton Woods' in the 1970's, policies on national and regional levels have prevailed over multilateral and international solutions. As discussed in the previous chapter, this situation raised a trade-off between domestically-oriented policies and the stability of the global monetary order. ${ }^{2}$

Consequently, it is contended that the main causes of this imbalance are attributable to the current design of the international monetary order, a system mainly based on monetary sovereignty attributes of the states and soft international governance. ${ }^{3}$ This state of affairs makes the case for the application of the emerging doctrine of common concern of humankind (Common Concern) ${ }^{4}$ as an adequate methodological approach to cope with the underprovision of the

1 On the overlapping jurisdictions dealing with public goods Petersmann remarks that: As international public goods (like transnational rule of law, international financial, and energy security) are composed of, and dependent on, national public goods, prioritization of national public goods is morally justifiable and democratically inevitable. Yet, protection of national public goods often remains incomplete without simultaneous protection of international public goods (e.g. providing for reciprocal elimination of border discrimination and transnational pollution undermining national public goods).

E U Petersmann, 'International Economic Law, 'Public Reason', and Multilevel Governance of Interdependent Public Goods' (2011) 14(1) JIEL 3 O.

2 See chapter 2 of this book.

3 Drahos pointed out that: Increasingly the regulation of public goods takes place by means of global standards. When, for example, the Basel Committee on Banking Supervision issues guidelines on capital adequacy standards that are adopted by the world's central banks, the stability that these and other guidelines bring to the world's financial system is a global public good.

Peter Drahos, 'The Regulation of Public Goods' (2004) 7(2) JIEL 321.

4 Hereafter, the term 'Common Concern' or 'Common Concern of Humankind' in capital letters will be used to describe the doctrine and emerging principle as proposed to be applied in this book and the term 'common concern of humankind' or 'common concern' in small letters will be used to describe the general principle as used in international instruments and most of literature. Cottier develops the emerging doctrine and principle in Thomas Cottier, 
GPG of international monetary stability and the debate about global cooperation and unilateral measures in monetary affairs.

To address the main issues associated with this trade-off, this chapter starts by exploring the concept of monetary stability as a local and also a global public good. It is followed by a description of the emerging doctrine and eventual principle of Common Concern as a valuable method to deal with collective action problems. It continues with a preliminary consideration of the threedimensional approach proposed by the doctrine starting with the duty to cooperate in monetary affairs both from a top-down approach (international level of governance) and a bottom-up approach (central banking cooperation). The section continues by examining domestic obligations concerning monetary stability with an emphasis on the special role of central banks and also by examining some cases of unilateral actions and issues of extraterritoriality in the pursuit of monetary stability. Lastly, it offers some remarks on securing compliance with obligations that may emerge from an accepted Common Concern of international monetary stability. This chapter concludes with a description of the complexities that the Common Concern preliminary analysis exposes in the pursuit of monetary stability and offers some guidelines for the following chapters.

\section{Monetary Stability as a Global Public Good}

The term 'public good' is a key concept in economics introduced by Paul Samuelson in the 1950's and is mainly applied at the local or national level. ${ }^{5}$ A public good has two essential characteristics: 'non-rivalry' in consumption and 'non-excludability' of benefits. ${ }^{6}$ The first characteristic implies that the use of the public good by one person will not diminish its availability to others. The second characteristic denotes that the public good is available to everybody, whether they contribute to its production or not.

It was only in the 199o's that the theory of public goods was first applied at the global or international level with the expression 'global public goods'

'The Principle of Common Concern of Humankind' in Thomas Cottier (ed) 'The Prospects of Common Concern of Humankind in International Law' (CUP 2O21).

5 Paul Samuelson, 'The Pure Theory of Public Expenditure' (1954) 36 Rev Econ Stat 387.

6 Samuelson's study focused on the first characteristic of 'non-rivalry' while the second characteristic of 'non-excludability' was introduced by Musgrave. See Richard A Musgrave, 'Public Goods' in Brown E Cary and Robert M Solow (eds), Paul Samuelson and Modern Economic Theory (McGraw Hill 1983). 
gaining interest among the works of the United Nations Development Programme (UNDP). ${ }^{7}$ In 2003 the International Task Force on Global Public Goods was created and in 2006 it issued its final report defining the concept of 'global public goods' as 'issues that are broadly conceived as important to the international community, that for the most part cannot or will not be adequately addressed by individual countries acting alone and that are defined through a broad international consensus or a legitimate process of decisionmaking. 8 Consequently, from this definition it is argued that 'Global public goods are those whose benefits could in principle be consumed by the governments and peoples of all states' and therefore 'consumption of the good by one state or its people in no way reduces its availability to others. ${ }^{9}$ This approach is in line with the qualities of 'non-rivalry' in consumption and 'non-excludability' of benefits of public goods as developed in the applicable theory from an economic perspective. ${ }^{10}$

While the provision of public goods at the national level requires the action of a single state, the provision of GPG S demands collective action at the international level. Both national public goods and GPG s create positive externalities (attributable to their characteristic of non-excludability of benefits). Whereas in the former case the externalities are intended to reach the population of a nation state within its geographical borders, in the latter case the externalities reach every country and the world wide population regardless of geographical and political borders. Therefore, in the absence of adequate international governance, there is a need for collective action and international cooperation among states for the production of GPG s. As remarked by Kaul, 'GPG s are public in the sense that they affect us all, and they are public in provision. It would be difficult for any nation to improve the availability of

$7 \quad$ The research on global public goods performed by the UNDP resulted in three publications. See Inge Kaul, Isabelle Grunberg and Marc Stern (eds), Global Public Goods: International Cooperation in the 21st Century (oup 1999); Inge Kaul and others (eds), Providing Global Public Goods: Managing Globalization (OUP 2003); Inge Kaul and Pedro Conceiçao, The New Public Finance: Responding to Global Challenges (OuP 2006).

8 International Task Force on Global Public Goods, Meeting Global Challenges: International Cooperation in the National Interest (Final Report, Stockholm, 20o6) $13<$ https://ycsg. yale.edu/sites/default/files/files/meeting_global_challenges_global_public_goods.pdf> accessed 21 October 2021.

9 ibid.

10 For an excellent description on the evolution of the theory of global public goods see Annamaria Viterbo, International Economic Law and Monetary Measures (E E 2012) ch 1. 
a GPG ... through domestic policy initiatives alone. Most GPG s call for crossborder cooperation..1

The main problems associated with the provision or underprovision of GPG $\mathrm{s}$ are threefold - the 'free-riding' or 'easy riders' issue, market failures, and government failures. The first problem is associated with the 'non-excludable' quality of the GPGs. This appears when some states rely on the provision of the GPG by some other states, letting themselves enjoy the benefits of the GPG for free and thus taking a 'free' or 'easy ride'. The second and third problems are the results of two types of failures. Market failure occurs when a market fails to provide the GPG or it provides the GPG in an inadequate manner. A government failure in the provision of GPG $s$ is a failure of global governance. As explained by Kaul, 'GPG s tend to involve policy interdependence among countries, because in most instances no nation, however powerful, can self-provide these goods. They require international cooperation based on a blend of fairness and power politics ....'12 This failure is exacerbated by the interference of national self-interests in the production of GPG s, which happens when states put their national interests above the global interest and therefore do not make appropriate commitments at the international level. This is identified in literature as a jurisdictional gap', that is, the gap among nation-states in charge of making policies within their territories and GPGS with transboundary benefits. ${ }^{13}$

Consequently, an effective international cooperation within the multilevel governance structure is needed. ${ }^{14}$ This requires active participation by the authorities at the different levels of governance (local, national, regional and international) in the production of GPG s. ${ }^{15}$ In the absence of an adequate

11 See Inge Kaul, 'Global Public Goods and Responsible Sovereignty' (The Broker, 1 July 2010) <https://www.thebrokeronline.eu/special-report-collective-self-interest/> accessed 21 October 2021.

12 Inge Kaul, 'Global Public Goods: Explaining their Underprovision' (2012) 15(3) JIEL 729.

13 See Inge Kaul, Isabelle Grunberg and Marc Stern (eds), Global Public Goods: International Cooperation in the 21st Century (n 6).

14 On the topic of multi-layered or multilevel governance see Thomas Cottier, 'Challenges Ahead in International Economic Law' (1999) 12(1) JIEL 3, 15; Thomas Cottier and Maya Hertig, 'The Prospects of 21st Century Constitutionalism' (2003) 7 Max Planck Yearbook of United Nations Law 261; Thomas Cottier, 'Multilayered Governance, Pluralism and Moral Conflict' (2009) 16(2) IJGLS 647; Thomas Cottier, 'Towards a Five Storey House' in C Joerges and E U Petersmann (eds), Constitutionalism, Multilevel Trade Governance and International Economic Law (Hart Publishing 2011); E U Petersmann, 'Framework of Analysis: Multilevel Governance' in Thomas Cottier and others (eds), The Rule of Law in Monetary Affairs (CUP 2014).

15 Petersmann justifies the application of the multilevel governance theory to the provision of GPG s by stating that: Multilevel governance is a normative necessity for the collective supply of most international public goods. The inadequate regulation of international 
international regulatory framework for the provision of GPG s, the role of states as the main providers of such goods becomes more relevant in a multilevel governance context. Therefore, legal doctrine suggests that a state should have an 'intermediary state' role between the national and international interests to address the challenges posed by the underprovision of GPG s. ${ }^{16}$ In doing so, some literature suggest that a state should exercise its sovereignty in a responsible manner considering not only the responsibility owed to its own citizens but also assuming the responsibility towards the international community for the external effects of their actions. ${ }^{17}$

Monetary stability, an indisputable national 'public good', has become increasingly globalized and also developed as a GPG for the international community. Michel Camdessus, former managing director of the International Monetary Fund (IMF), argued in 1999 that both the international monetary system and the international financial system should be considered GPGs on the premise that:

It is essentially the same system for everyone. If it works well, all countries have the opportunity to benefit; if it works badly, all are likely to suffer. Hence, all have an interest in reforms that will improve the system for the global public benefit. And, as is so frequently true for public goods, not many people care for, and even fewer are prepared to pay for, its improvement even if many comment about it. ${ }^{18}$

financial markets confirms that collective supply of most international 'aggregate public goods' - like the international monetary system aimed at protecting monetary stability, liberal trade and international freedom of payments - requires going beyond 'realist', 'liberal', 'functional' and 'public choice' strategies by 'embedding' multilevel governance into 'multilevel constitutionalism' protecting rights of citizens, general consumer welfare and transnational rule of law 'bottom up' and justifying international public goods regimes in terms of human rights and domestic constitutional law. Transnational rule of law is essential for the democratic legitimacy, effectiveness and overall coherence of interdependent 'aggregate public goods'.

ibid E U Petersmann, 'Framework of Analysis: Multilevel Governance' 458 (footnote omitted).

16 The 'intermediary state' is a legal doctrine that promotes debate about the role of the states' sovereignty in the new globalized order. See John H Jackson, 'Sovereignty Modern: A New Approach to an Outdated Concept' (2003) 97(4) AJIL782.

17 See Kaul, 'Global Public Goods and Responsible Sovereignty' (n 11).

18 See Michel Camdessus, 'International Financial and Monetary Stability: A Global Public Good? - Remarks by Michel Camdessus' (ImF/Research Conference, May 28 1999) <https://www.imf.org/en/News/Articles/2015/og/28/o4/53/spo52899> accessed 21 October 2021. On monetary and financial stability as global public goods see, inter alia, Barry Eichengreen, 'Hegemonic Stability Theories of the International Monetary System' (March 1987) NBER Working Papers No 2193; Ettore Dorrucci and Julie McKay, 
Accordingly, it can be argued that international monetary stability has the public good qualities of being non-rivalrous in its enjoyment and providing nonexcludable benefits. This consideration was reinforced by events that occurred during the Global Financial Crisis (GFC) - 'The 2007-2010 crisis demonstrated that a coordinated global response was necessary to minimize free riding and negative spillovers and that global institutions should be strengthened and supported. ${ }^{19}$

The increase in the spillover effects, which originated from decisions taken by the domestic monetary authorities since the beginning of the GFC, is the main example on this point. As remarked by Dorrucci and McKay, 'this neglect of the longer-term impact of domestic policies was one of the root causes of the global financial crisis' ${ }^{20}$ This situation highlighted both market and government failures and the consequent underprovision of the GPG of monetary stability.

As Lastra reminds us, 'It is the existence of market failures and deficiencies that provides the economic rationale for banking regulation'. She also states 'that is why a key aim of regulation is to internalize such externalities'. ${ }^{21}$ Hence, it can be argued that the GFC revealed not only the market imperfections with an inadequate domestic regulatory framework to internalize negative externalities but also the absence of an appropriate international regulatory framework to ensure the provision and protection of the GPG of international monetary stability. On this point, Viterbo argues that the consideration of both international financial and monetary stability as GPG S provides 'a powerful way to explain why we need more global regulation and international cooperation to avoid the future occurrence of economic meltdowns and to reap the benefits of globalization.22

'The International Monetary System After the Financial Crisis' (February 2011) 123 ЕС B Occasional Paper Series and Christian Tietje, 'The Role of Law in Monetary Affairs: Taking Stock' in Thomas Cottier and others (eds), The Rule of Law in Monetary Affairs (CU P 2014).

19 Viterbo, International Economic Law (n 10) 33.

20 These authors consider that monetary stability as a GPG includes two goods - international currency and external stability. See E Dorrucci and J McKay, 'The International Monetary System After the Financial Crisis' (n 18).

21 Rosa M Lastra, International Financial and Monetary Law (2nd edn, OU P 2015) 113.

22 Viterbo, International Economic Law (n 10) 10. 


\section{Common Concern of Humankind - Review of Literature and Evolution of the Principle}

Common Concern refers to 'an important shared problem and shared responsibility, and for an issue which reaches beyond the bounds of a single community and state as a subject of international law. ${ }^{23}$ This incipient doctrine promotes Common Concern as a new principle in international law that redefines the responsibilities of states concerning the promotion and protection of GPGs by adding an extra layer of responsibility beyond their jurisdictional domains. Common Concerns and public goods correlate with each other at the different levels of governance but they are not the same. As stated by Cottier:

The scope of public goods therefore is broader and different from Common Concerns of Humankind, properly speaking. The latter, as a concern, focuses on a number of serious problems threating peace, stability and welfare in the long run where public goods need to be created and protected while appropriate structures to this effect are not yet properly in place. $^{24}$

The nature of problems associated with Common Concerns calls for a collective action response and demands cooperation among states. Under this doctrine, international cooperation among states is the preferred approach to solve the problems associated with Common Concerns, and unilateral lawful action stands as the second best approach.

\subsection{Expression in Treaties and Scholarly Work}

The emerging doctrine of common concern of humankind has its roots in the concept of common interests in the context of the nineteenth century discussions on global commons and the protection of the high seas. ${ }^{25}$ Cottier also

23 In this section I rely extensively on Cottier's recent work on the emerging doctrine of Common Concern of Humankind. Cottier, 'The Principle of Common Concern of Humankind' (n 4).

24 Cottier, 'The Principle of Common Concern of Humankind' (n 4) 44.

25 Brunnée considers common concern as part of the doctrine of common interest, Jutta Brunnée ‘Common Interest - Echoes from an Empty Shell?' (1989) 49 Heidelberg Journal of International Law 791. Also see, Arvid Pardo and Carl Q Christol, 'The Common Interest: Tension Between the Whole and the Parts' in R Macdonald and D Johnston (eds), The Structure and Process of International Law (Martinus Nijhoff Publishers 1993). Others connect the origins of common concern of humankind to the public trust doctrine. Ved P Nanda and William K Ris, Jr, 'The Public Trust Doctrine: a Viable Approach to International Environmental Protection', (1976) 5(2) Ecology Law Quarterly 291. 
highlights that the notion of common concern of humankind was initially discussed as a response to the concept of common heritage of mankind ${ }^{26}$ avoiding property allocations. ${ }^{27}$ While common heritage of mankind proposes to constrain national sovereignty common concern of humankind respects the principle of permanent sovereignty. ${ }^{28}$ Common Concern of Humankind as an emerging doctrine and eventually a legal principle does not challenge existing foundations of public international law and aims to fit into the Westphalian system of nation states that is characterised by sovereign equality, the prohibition of use and threat of force and of occupation and appropriation of territory.

The international law discourse referred to this principle generally in connection with the field of environmental law $^{29}$ and has recently moved the discussion to the field of international human rights protection in general. ${ }^{30}$ Nakavukaren Schefer and Cottier developed the relationship to the emerging responsibility to protect $\left(\mathrm{R}_{2} \mathrm{P}\right)$ in international humanitarian law and suggested that $\mathrm{R}_{2} \mathrm{P}$ amounts to perhaps the most advanced area of Common Concern, as it not only entails a right, but also an obligation, to act abroad. ${ }^{31}$ Cottier considers that jus cogens could be conceptualised in terms of a principle of Common Concern of Humankind. ${ }^{32}$ Kontolemis presents it as suitable for the case of

26 Kemal Baslar, The Concept of Common Heritage of Mankind in International Law (Martinus Nijhoff Publishers 1998); Rüdiger Wolfrum, 'The Principle of Common Heritage of Mankind', (19983) 43 Heidelberg Journal of International Law 312. Judge Cançado Trindade contemplates that common concern of humankind as a derivative concept of common heritage of mankind, A A Conçado Trindade, International Law for Humankind: Towards a New Jus Gentium (2nd ed, Martinus Nijhoff Publishers 2013) 344, 348 and 352.

27 Mostafa Tolba, "The Implications of the "Common Concern of Mankind" Concept on Global Environmental Issues' (1991) 13 Revista Instituto Interamericano de Derechos Humanos 237, 240; Jutta Brunnée, 'Common Areas, Common Heritage and Common Concern' in Daniel Bodansky, Jutta Brunnée and Ellen Hey (eds), The Oxford Handbook of International Environmental Law (OUP 2007).

28 Cottier, 'The Principle of Common Concern of Humankind' (n 4) 51.

29 See Laura Horn, "The Implications of the Concept of Common Concern of a Human Kind on a Human Right to a Healthy Environment' (2004) 1 Macquarie Journal of International and Comparative Environmental Law 233; Thomas Cottier and others, 'The Principle of Common Concern and Climate Change' (2014) 52(3) Archiv des Volkerretchts 293.

30 Charles R Beitz, 'Human Rights as a Common Concern' (2001) 95(2) American Political Science Review 269 .

31 Krista Nakavukaren Schefer and Thomas Cottier, 'Responsibility to Protect (R2P) and the Emerging Principle of Common Concern' in Peter Hilpold (ed), The Responsibility to Protect; A New Paradigm of International Law? (Brill Nijhoff 2014).

32 Thomas Cottier, 'Improving Compliance: Jus Cogens and International Economic Law' (2015) 46 Netherlands Yearbook of International Law 329. 
exchange rate policies. ${ }^{33}$ Moreover, Cottier and Matteotti explored the limitations imposed on the principle of Common Concern by the disciplines of the law of the World Trade Organisation. ${ }^{34}$

There are references to common concern in international treaty language in relation to climate change (1992 UN Framework Convention on Climate Change and The 2015 Paris Agreement), biodiversity protection (1992 Biodiversity Convention), plant genetic resources (2001 International Treaty on Plant Genetic Resources for Food and Agriculture) and cultural goods in a broad sense (Preamble of the 2003 UNEsCo Convention for Safeguarding of the Intangible Cultural Heritage). ${ }^{35}$

The 1992 UN Framework Convention on Climate Change (UNFCCC) states that 'change in the earth's climate and its adverse effects are a common concern of humankind: ${ }^{36}$ The preamble of the 2015 Paris Agreement related the common concern of humankind to human rights and intergenerational equity: ${ }^{37}$

Acknowledging that climate change is a common concern of humankind, Parties should, when taking action to address climate change, respect, promote and consider their respective obligations on human rights, the right to health, the rights of indigenous peoples, local communities, migrants, children, persons with disabilities and people in vulnerable situations and the right to development, as well as gender equality, empowerment of women and intergenerational equity, ...

The 2017 Declaration of Ethical Principles reaffirms climate change as a common concern and recognises the need for a multilevel governance effort: 38

33 Zenon Kontolemis, 'Exchange rates are a matter of common concern: policies in the run-up to the euro?' (No 191 Economic Papers, Directorate-General for Economic and Financial Affairs Publications 2003).

34 Thomas Cottier and Sofya Matteotti, 'International Environmental Law and the Evolving Concept of "Common Concern of Mankind" ' in Thomas Cottier, Olga Nartova and Sadeq Z Bigdeli (eds), International Trade Regulation and the Mitigation of Climate Change (cuP 2009) 21.

35 See respectively, United Nations Framework Convention on Climate Change (1992) 31 ILM 849, 851; Adoption of the Paris Agreement (2015) FCCC/CP/2015/L.9/Rev.1, 21; Convention on Biological Diversity (1992) 31 ILM 818, 822; International Treaty on Plant Genetic Resources for Food and Agriculture (2001) 2400 UNTS 303, 379; Convention for the Safeguarding of the Intangible Cultural Heritage (2003) 2368 UNTS 3, 35.

$36 \quad$ United Nations Framework Convention on Climate Change (n 35).

37 Adoption of the Paris Agreement (n 35).

38 Declaration of Ethical Principles in relation to Climate Change (13 November 2017) <http:// portal.unesco.org/en/ev.php-URL_ID=49457\&URL_DO=DO_TOPIC\&URL_SECTION= 201.html $>$ accessed 21 October 2021. 
Also recognizing that climate change is a common concern for all humankind, and convinced that the global and local challenges of climate change cannot be met without the participation of all people at all levels of society including States, international organizations, sub-national entities, local authorities, indigenous peoples, local communities, the private sector, civil society organizations, and individuals, ...

The 1992 Biodiversity Convention also states that 'conservation of biological diversity is a common concern of humankind'. ${ }^{39}$ The International Treaty on Plant Genetic Resources for Food and Agriculture affirms 'that plant genetic resources for food and agriculture are a common concern of all countries, in that all countries depend very largely on plant genetic resources for food and agriculture that originated elsewhere' 40 The term is also used for the preservation of intangible cultural heritage in a broad sense. The preamble of the unesco Convention for the Safeguarding of the Intangible Cultural Heritage considers 'the universal will and the common concern to safeguard the intangible cultural heritage of humanity'41

The International Law Commission (ILC) of the United Nations considered common concern of humankind in its debate about the legal protection of the atmosphere. In his second report, rapporteur Shinya Murase described in detail the emerging concept of common concern of humankind and recommended to recognise that the degradation of the atmosphere amounts to a common concern of humankind:

\section{Draft Guideline 3: Common concern of humankind}

The atmosphere is a natural resource essential for sustaining life on Earth, human health and welfare, and aquatic and terrestrial ecosystems, and hence the degradation of atmospheric conditions is a common concern of humankind. ${ }^{42}$

The second report on the protection of the atmosphere is the most extensive official document on common concern within the United Nations, as of today. The rapporteur reviewed extensively the references to common concern of humankind in existing treaties and literature, its connections to common

39 Convention on Biological Diversity (n 35).

40 International Treaty on Plant Genetic Resources for Food and Agriculture (n 35).

41 Convention for the Safeguarding of the Intangible Cultural Heritage (n 35$)$.

42 Shinya Murase, 'Second report on the protection of the atmosphere' (A/CN.4/681, International Law Commission, 67th session, Geneva, 2 March 2015) 25, 49. 
heritage, duties to cooperate and community obligations erga omnes. He acknowledges the emerging but still undefined status of common concern of humankind and he suggests including degradation of the atmosphere as a common concern of humankind to be promoted and protected. ${ }^{43}$

The suggestion to consider the degradation of the atmosphere as a common concern of humankind was ultimately opposed to by the Commission on the grounds that the concept is not known in the context of degradation of atmospheric conditions and that there is no evidence in state practice and, thus, should not be used. ${ }^{44}$ In consequence, reference to common concern of humankind was removed in subsequent discourse on the protection of the atmosphere. On these objections made by the ILC of the UN, Cottier comments that:

The renewed recognition of common concern of humankind in the 2015 Paris Agreement renders some of the objections made in the ILC obsolete. The problem of lacking precision and undefined and vagueness remains and needs to be addressed. Yet, rejecting common concern as a potential principle for such reasons reflects a strong positivist tradition which ignores the function of the ILC to contribute to the evolution of international law in addressing real life problems of the international community. (...) While some restraint may be justified in terms of a narrowly understood mandate of the ILC, rejecting the concept regrettably is an opportunity missed..$^{45}$

In line with Cottier, this chapter considers that the emerging doctrine of Common Concern bears the potential to develop into a principle of law applicable in a multilevel governance structure and beyond the field of natural resources and environmental law. As stated by French, the emerging doctrine must 'provide normative coherence as to why certain issues are of common concern and some are not' because if not 'there is a real risk that the discussion descends into little more than retrospective realpolitik. ${ }^{46}$

\footnotetext{
43 ibid $17-25$.

44 International Law Commission, 'Provisional summary record of the 3246th meeting' (A/ CN.4/SR.3246, 67th Session (first part), 11 January 2016) 4-5.

45 Cottier, 'The Principle of Common Concern of Humankind' (n 4).

46 Duncan French, 'Common concern, common heritage and other global(-ising) concepts: rhetorical devices, legal principles or a fundamental challenge?' in Michael Bowman, Peter Davies and Edward Goodwin (eds), Research Handbook on Biodiversity and Law, 344 (E 2016).
} 


\subsection{Foundations and Evolution of the Principle}

According to the Oxford Dictionary the term common not only refers to the ordinary, but also something 'Shared by, coming from, or done by two or more people, groups, or things', or 'Belonging to or involving the whole of a community or the public at large. ${ }^{47}$ The noun concern contains a proposition of 'anxiety, worry', but also 'a matter of interest or importance to someone.48 As suggested by literature and treaty language, the expression 'common concern of humankind' comprises a shared problem and a shared responsibility for the international community as a subject of international law.

The International Court of Justice (ICJ) in the Barcelona Traction case recognised that international law comprises obligations owed to the international community of states as a whole rather than to particular states. In this decision the ICJ consider that the obligations owed to the international community, 'by their very nature ... are the concern of all States'. ${ }^{49}$ Therefore, the issues categorised as Common Concerns require a 'collective action' response and demand 'international cooperation' among states. ${ }^{50}$ In this line Bodansky considers that 'One way of conceptualizing these obligations erga omnes is in terms of global public goods: if an obligation primarily relates to the provision of a global public good or the prohibition of a global public bad, then the obligation protects a 'collective' or 'common' interest and should be owed to the international community of states as a whole. 51

Common Concern as an emerging principle in international law aims to redefine the responsibilities of the states concerning the promotion and protection of GPG s. Bodansky remarks that 'Although international law does not recognise the category of "global public goods", several international law concepts bear a close relationship to it'.52 Common Concern is one of the concepts that relates intrinsically to GPGs, but they are not the same. Basically, while

47 'Meaning of common in English' (Lexico) <www.lexico.com/definition/common> accessed 21 October 2021.

48 'Meaning of concern in English' (Lexico) < www.lexico.com/definition/concern > accessed 21 October 2021.

49 Barcelona Traction, Light and Power Company, Limited, ICJ Reports 1970, 3, 32.

50 According to Cottier and others, "The term "collective action problem" describes a situation in which multiple individuals would all benefit from a certain action, which, however, has an associated cost that makes it implausible that any one individual can or will undertake and solve it alone'. See Cottier and others, 'The Principle of Common Concern and Climate Change' (n 29).

51 Daniel Bodansky, 'What's in a Concept? Global Public Goods, International Law, and Legitimacy', (2012) 23(3) EJIL 651.

ibid. 
Common Concern refers to an unresolved international issue, public goods are non-rivalrous and non-excludable goods. Hence, Common Concern intervenes when there is an underprovision or deficiency of a GPG. Common Concerns are global but also exist at the local and regional levels of governance and correlates with the public goods appropriate at each level. On this point Cottier and others consider that 'Local common concerns call for different answers from global common concerns. What they share is that a problem exceeds a single community and it should ideally be addressed with a cooperative effort. In both cases the law needs to answer the question of what to do if such cooperation fails to materialise. ${ }^{53}$

The literature on both GPGs and Common Concern recognise that the underprovision of GPG s justifies and triggers the need for international cooperation among states to provide and promote GPG s for the benefit of humanity. However, while recognising that international cooperation among states remains the best outcome to solve the problems associated with Common Concerns, this emerging principle proposes the use of unilateral lawful action as the second best approach in case of failure or absence of cooperation. In this regard, Cottier and others state that 'The principle of Common Concern, understood beyond co-operation, seeks then to delineate obligations to act, and rights to act beyond the scope of territorial application of laws of the nation states. The understanding is informed by the experience gained in trade policy, where unilateral action, or the threat of it, triggered co-operation .....54

Beyond economic and political considerations, it can be stated that the main reason for failure of cooperation at the global level is rooted in the current legal and institutional design of the multilevel system of governance. That is, as mentioned before, powerful sovereign states driven by domestic interests, and soft-law arrangements and weak institutions at the international level. In this context, Common Concern aims to work as a foundation to strengthen international cooperation and also to define and legitimize unilateral domestic measures in the absence of adequate cooperation. On this issue it has been

53 Cottier and others, 'The Principle of Common Concern and Climate Change' (n 29) 293.

54 ibid 321 . Kiss sustained that common concern, as a concept provides the basis for the international community to act. However, he pointed out that such right and duty of the international community should be balanced with national sovereignty. Alexandre Kiss, 'The Common Concern of Mankind' (1997) 27 Environmental Policy and Law 244, 246-247. Later on, Shelton argues in the same position as Kiss, Dinah Shelton, 'Common Concern of Humanity' (2009) 5 Iustum Aequum Salutare 33, 38. 
argued that states should 'take domestic action as a matter of international law'.55

It is in this context that international cooperation within the multilevel governance structure is needed. Common concerns are not restricted to the international level but can also be found at the domestic and regional levels of governance. Hence, the process of claims and responses will determine the level of governance at which the Common Concern in question is better addressed, and the theories relating to multilevel governance provide valuable assistance for such considerations.

These multilevel or multilayered governance doctrines encompass diverse constitutional theories, a human rights based approach, sovereignty concerns and global administrative law considerations. ${ }^{56}$ These doctrines aim to contribute to an optimal promotion and protection of public goods at the different levels of governance, which are informed not only by states and international organisations but also non-state actors. ${ }^{57}$ Within these doctrines, the 'five storey house' doctrine in particular argues that all levels of governance are of equal relevance but recognises that the international level has a key role to play in the pursuit of GPG s, which include Common Concerns. ${ }^{58}$ To complement these multilevel governance doctrines Cottier argues that:

Common Concern will help refining jurisdiction in matters, which no longer can be dealt with on the basis of strict territorial application of domestic law; it will explore channels of mobilising non-state actor action to resolve Common Concern issues through participation and deliberation in the broader and more transformative sense of reinvention of

55 ibid. On this point, Ahmad raised the debate about the co-existence of the duty to cooperate and the unilateral domestic measures. See Zaker Ahmad, 'State Responsibility Aspects of a Common Concern Based Approach to Collective Action' in Samantha Besson (ed), International Responsibility Essays in Law, History and Philosophy (Schulthess 2017) 107.

56 For multilevel governance doctrines see: on constitutional theories, Neil Walker, 'The Idea of Constitutional Pluralism' (2002) 65 Modern Law Review 317; Anne Peters 'Compensatory Constitutionalism: The Function and Potential of Fundamental International Norms and Structures' (2006) 19 Leiden Journal of International Law 579; on human rights considerations, Ernst-Ulrich Petersmann, International Economic Law in the 21st Century: Constitutional Pluralism and Multilevel Governance of Interdependent Public Goods (Hart Publishing 2012); for the administrative law-based approach, Benedict Kingsbury and others (eds), 'The Emergence of Global Administrative Law' (2005) 68 Law and Contemporary Problems 1.

57 E U Petersmann, 'Framework of Analysis: Multilevel Governance' in Thomas Cottier and others (eds), The Rule of Law in Monetary Affairs (n 14).

58 Cottier, 'Towards a Five Storey House' (n 14). 
governance. Yet, states and government continue to play a key role. The multitude of actors does not undermine the structure of multi-layered governance. 59

It is in this context that the notion of 'cooperative sovereignty', as explained in chapter 2 of this book, also applies. Besson's findings on general sovereignty in correlation to the multilevel governance approach argue that:

gradually the exercise of sovereignty has turned from an individual exercise into a cooperative enterprise ... sovereign political entities can no longer exercise their traditional competences and functions alone ... This form of sovereignty triggers duties of cooperation on the part of the entities which cannot ensure the protection of all the values they should protect, as much as on the part of the entities which can help the former to protect those values they share. They should all be seen as working towards the same end: their realization of their shared sovereign values and principles. ${ }^{60}$

These considerations on general sovereignty also apply to monetary sovereignty as there is a correlation among the public good of monetary stability at the different levels of governance that must be protected and promoted on a cooperative manner.

Despite the aforementioned references to Common Concern in treaty language, the normative concept and implications of the emerging doctrine are not yet specified. Cottier, in what can be considered the most extensive and comprehensive work on the concept and emerging doctrine of Common Concern of Humankind acknowledges that:

Common concern of humankind, so far, has mainly been a source of inspiration. It encourages and stimulates taking up responsibilities and to reflect and to develop appropriate policy instruments in addressing a challenge of magnitude. As a source of inspiration, it assists in developing new forms of cooperation, funding and interaction emerging in state practice and treaty-making. It thus is able to influence, as a powerful message, the evolution of development of international law in the age of globalization facing new types of challenges beyond longstanding threats

59 Cottier, 'The Principle of Common Concern of Humankind' (n 4) 46.

6o Samantha Besson, 'Sovereignty in Conflict' (2004) 8 European Integration Online Papers $13<$ https://papers.ssrn.com/abstract=594942> accessed 21 October 2021. 
to international peace and security addressed in the United Nations Charter. ${ }^{61}$

At the same time, Cottier recognises the main objections that may arise in response to the emerging doctrine:

the notion is devoid of a normative concept and thus part of hortatory treaty language of no legal consequence. It may deploy symbolic and psychological effects. It may stimulate debate and action, emphasizing the seriousness of a problem. Indeed, the description of common concern in the 2015 Paris Agreement encompasses all kinds of inflationary aspirations which render meaning difficult beyond existing normative concepts in public international law. Moreover, it can be easily objected that the scope is limited to specific declarations and treaties calling upon common concern in specific areas of environmental law; it therefore cannot be applied in terms of a general principle. Finally, it may be argued that common concern does, and cannot, not amount to a general principle if law. ${ }^{62}$

This book, while acknowledging the objections to the emerging doctrine of Common Concern, aims to test the value and feasibility of the application of this doctrine to the case of international monetary stability using the special approach proposed by Cottier, detailed below.

Cottier argues that Common Concern may evolve as a legal principle within a process of claims and responses that will determine its contours and normative contents. ${ }^{63}$ The differentiation between principles and rules acquires relevance in this process. ${ }^{64}$ While rules are specific and apply in a particular context, legal principles aim to provide guidance and directions. ${ }^{65}$ Cottier also asserts that the development of Common Concern as an emerging principle may follow the footsteps of the established principles of international law such

\footnotetext{
61 Cottier, 'The Principle of Common Concern of Humankind' (n 4) 26.

62 ibid.

63 ibid 26.

64 Ronald M Dworkin, 'The Model of Rules' (1967) 35(1) The University of Chicago Law Review 14.

65 Robert Kolb, 'Principles as Sources of International Law (With Special Reference to Good Faith)' (2006) 53(1) Netherlands International Law Review; Jan Wouters, Dominic Coppens and Dylan Geraets, 'The Influence of General Principles of Law' in Sanford E Gaines and others (eds), Liberalising Trade in the EU and the WTO - A Legal Comparison (Cambridge University Press 2012).
} 
as sovereignty, non-interference and self-determination and that the emerging doctrine can build upon existing legal disciplines and theories such as the traditions of equity, the doctrine of public trust, the doctrine of community interests and the essential function of law and legal principles to preserve peace and stability in society. ${ }^{66}$

International law recognises a state's sovereignty over its internal affairs within its territorial boundaries. Hence, sovereignty is usually defined as the supreme authority of a state within its own territory, only limited by the accepted rules of international public law. This aspect of sovereignty - i.e. the supreme authority in a given territory - derives from the traditional Westphalian concept of sovereignty and it relates to the notion of equality of states and the correlative duty of non-intervention by any foreign or international powers (unless consented to by the respective state). Hence, Jackson argued that there is an intrinsic connection between the concept of sovereignty and the very foundations and sources of international law. That is to say, that 'no international law norm is valid unless the state has somehow "consented" to it.'.67

Should Common Concern of Humankind develop as a principle of international law, it would inevitably affect or restrict a state's sovereignty over its affairs in connection to the common concern in question. These limitations to the state's sovereignty may attract some criticisms to the emerging doctrine of Common Concern on the grounds of national sovereignty, self-determination and liberty. However, Cottier remarks that the limitations that the principle of Common Concern may impose on the sovereignty of states will be done on a legal and consensual basis and thus he cannot see the basis for contention on these grounds. ${ }^{68}$

The emerging doctrine of Common Concern of Humankind aims to extend its applicability beyond the field of natural resources and environmental law by laying down the foundations and guidance to be applied across the board for public international law. The most recent studies encompass the application of the emerging doctrine to shared problems in income inequality, the realisation of the core and undeniable essence of human rights, the duty to

66 Cottier, 'The Principle of Common Concern of Humankind' (n 4) 26.

67 John H Jackson 'Sovereignty Modern: A New Approach to an Outdated Concept' (2003) 97 AJIL 786.

68 On this point Cottier considers that: As states need to agree to an emerging principle in treaty law and in the formation of customary law, these principles are respected. It is subject to consent and thus not different from other principles of international law. States are not obliged to sign and ratify treaties relating to Common Concern. They may persistently object to legal recognition in customary law.

Cottier, 'The Principle of Common Concern of Humankind' (n 4) 54. 
protect $\left(\mathrm{R}_{2} \mathrm{P}\right)$, the problem of migration, transfer of technology and problems relating to pollution of the high seas. ${ }^{69}$

\section{Common Concern of Humankind - Process of Claims and Responses}

It is argued that the process of claims and responses in order for an issue to amount to a Common Concern can be initiated both by states and non-state actors in the context of an international forum or organisation that deals with that specific area. Cottier considered that while the role of the Security Council of the United Nations is limited in this process (because it only deals with short term crises), the Group of 20 (G2O) should take the lead in the consideration of potential Common Concerns of horizontal nature and, in particular, when they involve economic issues. ${ }^{70}$

The benchmark or threshold for an issue to be considered a Common Concern is a threat to peace, stability and welfare. The main reason for having a threshold lies in the reality that not all collective action problems can be considered common concerns. The emerging doctrine aims to contemplate only those problems that, because of their seriousness and magnitude, cannot be solved by states in isolation and demand transboundary cooperation. ${ }^{71}$ The recognition of climate change and the loss of biological diversity as common concerns of humankind illustrate the level of seriousness of the issues to be contemplated under this emerging doctrine.

The considerations of peace, stability and welfare derive from the foundations of public international law - that some situations legitimise limitations to the traditional notions of state sovereignty, independence and self-determination. Hence, only problems in the various fields of public international law which potentially threaten peace, stability and welfare can act as the trigger to start the process of claims and responses in order for an issue to be considered a Common Concern of Humankind. Such threats are not limited to classic threats of warfare and aggression but also involve those with potential and disastrous implications such as climate change and loss of biodiversity. Hence, Cottier proposes that 'the threshold should be comparable to, and

69 Cottier, 'The Principle of Common Concern of Humankind' (n 4). This book deals with new collective action problems that may amount to novel common concerns of humankind in different fields of international public law and calls for further work to be done.

$70 \quad$ ibid 42.

71 ibid 39 . 
commensurate with, the one recognised in international law for threats to peace and security as defined by the UN Security Council and state practice.' ${ }^{72}$

The threat to international peace, stability and welfare does not provide specific criteria. Consequently, the benchmark will act as a trigger to start the process of claims and responses to determine whether a collective action problem is to be considered a Common Concern. The process of claims and responses should be analysed from a three-dimensional perspective. Firstly, enhancing the duty to cooperate, consult and negotiate (international cooperation among states). Secondly, providing the basis for obligations at home (responsibilities at the state level - homework) delineating not only the rights but also the duties of the states to act beyond the scope of the territorial application of laws in order to comply with international commitments made (extraterritoriality). Thirdly, securing compliance with the obligations that emerge from Common Concerns. ${ }^{73}$ These three elements are the essence of the potential legal principle of Common Concern of Humankind and go beyond existing rights and obligations under international law.

\subsection{The Duty to Cooperate}

The duty to cooperate, one of the key elements of the emerging doctrine of Common Concern, entails an improved transparency in information sharing and the timely and accurate publication of laws and regulations. This is aimed to increase mutual trust among the actors and intervene in the process of claims and responses. Hence, a principle of Common Concern would entail minimal standards to grant access to information upon request, and to publish relevant information, legislation, practices and precedents. Cooperation to address Common Concerns also involves the duty to consult and to negotiate in order to arrive at an agreement. Inherently, by acknowledging that a matter is a common concern, countries and authorities imply their willingness

72 ibid 39. International peace and security is dealt with by the states and the powers of the Security Council of the United Nations. United Nations, 'Peace and Security' <https:// www.un.org/en/our-work/maintain-international-peace-and-security> accessed 21 October 2021.

73 Cottier and others argued that while testing the emerging doctrine of Common Concern to climate change: The concept of Common Concern is intended to cover situations that fall outside the traditional categorization of state responsibility ... The concept covers situations of multiple state responsibilities, such as those in which states engage in concerted efforts or those in which states engage in independent actions, whether in breach of an international obligation or not, that cause damage to the environment.

Cottier and others, 'The Principle of Common Concern and Climate Change' (n 29) 315 . 
and readiness to consult and to negotiate in addressing the transboundary problem.

Cottier recognises that under current international law there is no general duty to cooperate, consult and negotiate but when one of such obligations exists it is usually enshrined in a treaty or based on customary international law. Thus, the emerging principle aims to enhance the duty to cooperate in matters that are considered as Common Concerns of Humankind. Duties to cooperate, consult and negotiate were firstly dealt with in the emerging field of natural resources and international environmental law ${ }^{74}$ and recognised specifically by the International Court of Justice in the 1974 Fisheries Jurisdiction Case in order to clarify the allocation of marine resources to competing interests. ${ }^{75}$ These duties can also be found within the multilateral trading system of the wTo. For example, wTo members are obliged to negotiate within trade rounds under good faith efforts to seek results and agreement. Another example is the obligation for member states, under the universal standards of UN law and the Friendly Relations Declaration, to settle their disputes by peaceful means in line with the prohibition to use or threaten to use force. ${ }^{76}$

Consultation and negotiation will involve discussions on the sharing of burdens and allocation of responsibilities among the actors involved in the specific subject matter to be considered as a Common Concern. On this point Cottier remarks that:

the recognition of a problem as a Common Concern always entails the basic obligation to make contributions by States commensurate with historical performance in creating the problem at hand, existing levels of GDP and other accepted indices, such as the Global Development Index (GDI), or specific indicators applicable to a particular policy area falling under the principle Common Concern. It strongly depends upon the subject matter. ${ }^{77}$

74 Frederic L Kirgis, Prior Consultation in International Law (University Press of Virginia 1983).

75 Fisheries Jurisdiction (United Kingdom v Iceland) Merits, Judgement, ICJ Reports 1974 P 3.

$76 \quad 2625$ (xxv) Declaration on Principles of International Law concerning Friendly Relations and Co-operation Among States in Accordance with the Charter of the United Nations', (United Nations General Assembly, 25th Session, Resolutions Adopted on the Reports of the Sixth Committee,24 October 1970) 121; see Helen Keller, 'Friendly Relations Declaration (1970)', Max Planck Encyclopedias of Public International Law IV (2012) 25 o.

77 Cottier, 'The Principle of Common Concern of Humankind' (n 4) 61. Also, Ahmad elaborates on burden-sharing and differentiated responsibility on issues considered as common concerns of humankind in his case study on the implications of Common Concern on transfer of technology in renewable energy. Zaker Ahmad, 'Trade-Related Measures 
He also recalls the principle of shared and differentiated responsibility in climate change adaption and mitigation under the 1992 Framework Convention and the 2015 Paris Agreement as an example of this point. ${ }^{78}$

In addition, Common Concern demands cooperation in the implementation of, and compliance with, international commitments through domestic law and policy. Cottier considers that in doing so:

Regulatory agencies assigned to comparable tasks in different countries shall exchange information, consult and work together with a view to prepare the ground for regulatory convergence and cooperation and implementation relating to the problem recognised as a Common Concern of Humankind. These activities also prepare the ground to foster co-operation in law enforcement, requiring specific rules to define jurisdiction and powers of authorities and courts of law in engaging in transboundary law-enforcement and recognition of foreign legal acts and judgments. ${ }^{79}$

Consequently, the recognition of a Common Concern in a specified area of international law should come with an advanced level of cooperation entailing mutual assistance by administrative bodies and judicial assistance by legal authorities, and thus eventually achieving legal integration.

\subsection{Obligation to Do Homework}

The emerging doctrine of Common Concern grants a special place to the obligations at the domestic level or obligations to do homework. The term 'homework' was introduced by the emerging doctrine as a legal denomination to encompass all the obligations that are attached to the principle of Common Concern of Humankind. With recourse to the doctrines of multilevel governance, the issues considered as common concern would engage the appropriate level of governance. Hence, this element encompasses not only the duty to promote and protect the Common Concern at the local level but also the duty to implement international commitments assumed in international agreements and in customary law. Construing international law in accordance with the principles

to Spread Low Carbon Technologies: A Common Concern Based Approach', in Thomas Cottier (ed) 'The Prospects of Common Concern of Humankind in International Law' (n 4).

78 ibid. On shared responsibility see André Nollkaemper, 'Issues of Shared Responsibility before the International Court of Justice' in Eva Rieter and Henri de Waele (eds), Evolving Principles of International Law; Studies in Honour of Karel C. Wellens (Martinus Nijhoff Publishers 2012).

Cottier, 'The Principle of Common Concern of Humankind' (n 4) 61. 
set out in Article 31 of the Vienna Convention on the Law of Treaties, Cottier remarks that the doctrine is not meant to affect the existing obligations under international law but to confer them with the foundations of the emerging principle of Common Concern. That is, encouraging the timely and effective implementation of international commitments and promoting bottom-up initiatives to address the global challenges presented by the Common Concerns.

Beyond the implementation of international commitments, the emerging doctrine aims to inspire autonomous domestic policymaking to address the issues underlying the Common Concerns. As in international law, Common Concern may also influence the interpretation and implementation of domestic law. For example, when international cooperation to safeguard a specific Common Concern is limited, lawful domestic unilateral measures with international effects are encouraged.

As stated in the 1927 Lotus rule ${ }^{80}$ and mostly developed in international criminal law and in competition law and policy, extraterritorial jurisdiction of states requires sufficient attachment to the territory of the state. However, it may be difficult to respect such jurisdictional attachment in the case of common concerns. The nature of the problems considered as Common Concerns are in their nature shared, transboundary problems, often of global reach. Hence, as clarified by Cottier:

Measures adopted in implementing international law obligations or of domestic measures may often deploy effects beyond the boundaries of the particular jurisdiction. International law does not exclude such effects, but seeks a careful balance between the interests of different jurisdiction. States are free to adopt measures having extraterritorial effect unless prohibited by international law. ${ }^{81}$

Common Concern as a principle of international law would not require such territorial linkages but would examine whether the measures and actions are able to support the classification of an issue as a Common Concern, as achieved by the international community during the process of claims and responses.

\subsection{Securing Compliance}

Last but not least, Cottier remarks that the most controversial aspect of the emerging doctrine and principle of Common Concern relates to securing

8o The Case of the S. S. Lotus (France v Turkey) (1927) PCIJ Series A, No 10. Also see Cedric Ryngaert, Jurisdiction in International Law (OUP 2008).

81 Cottier, 'The Principle of Common Concern of Humankind' (n 4). 
compliance with the obligations that emerge from Common Concerns. ${ }^{82} \mathrm{He}$ argues that there is a fundamental difference between the discretionary right of states to act under the existing mechanism of international law of sanctions and countermeasures, and the new obligation to act as suggested by Common Concern. This new obligation to act will apply only to identify Common Concerns within the process of claims and responses and will be subject to the principles of proportionality and accountability.

International law is characterised by voluntary compliance with international obligations. Most of the states comply voluntarily with international obligations as a matter of self-interest. ${ }^{83}$ As reciprocal interests are in place, compliance with international law usually does not rely on enforcement mechanisms. However, some areas of international law do not involve reciprocity and, thus, call upon additional disciplines to secure compliance with the obligations in place. It is here that the principle of Common Concern can play a role.

In the absence of reciprocity and mutual benefits, states may opt out and let others assume main responsibilities to produce global public goods. Other than in international trade and investment, which depend on immediate mutual benefits, such reciprocity is lacking in areas such as the issues of climate change, protection of biodiversity and migration. It is also the case in the field of human rights. ${ }^{84}$ In order to avoid free-riding, the emerging doctrine of Common Concern calls for the lawful implementation of instruments and incentives supporting international compliance and securing that a recognised Common Concern of Humankind is dealt with in priority in domestic and international processes.

Cottier recalls that these instruments are mainly found in the disciplines of state responsibility in international law. States are entitled to the use of countermeasures, subject to the prerogatives of the UN Security Council under Chapter VII of the UN Charter in response to threats on peace, and to

\footnotetext{
82 ibid 73 .

83 Edith Brown Weiss, 'Rethinking compliance with international law' in Eyal Benvenisti and Moshe Hirsch (eds), The Impact of International Law on International Cooperation (CUP 2004); Moshe Hirsch, 'Compliance with international norms in the age of globalization' in Eyal Benvenisti and Moshe Hirsch (eds), The Impact of International Law on International Cooperation (CUP 2004).

84 Bogdanova demonstrates that failures to comply with international obligations in the field of international human rights are endemic. Iryna Bogdonava, 'Reshaping the Law of Economic Sanctions for Human Rights Violations: The Potential of Common Concern of Humankind' in Thomas Cottier (ed) 'The Prospects of Common Concern of Humankind in International Law' (n 4).
} 
mandatory obligations of dispute settlement in the field of international trade regulation. States are entitled to the reestablishment of lawful conditions (restitutio in integrum), but usually opt for sanctions or countermeasures (in trade, the withdrawal of market access concessions) in order to remedy the violation and injury suffered.

In order to avoid free-riding and non-compliance, a matter recognised as a Common Concern may require all states involved to take countermeasures. Consequently, the emerging doctrine calls for a multilateral system and appropriate international institutions to secure compliance. On the eventual implications of an accepted principle of Common Concern, Cottier calls for a reform of the United Nations sanction system and a review of the task of the Security Council to collectively address failing states in areas recognised as a Common Concern of Humankind, unless the matter is assigned to specialised international organisation empowered to act against violations of the principle. However, he also recognises that, 'Given the difficulties to achieve such a goal, it remains imperative that individual states, and groups of states, for the time being, remain free to take recourse to unilateral economic measures on behalf of the international community in areas governed by the principle of Common Concern of Humankind? 85

In the absence of multilateralism, Common Concern provides the foundations of the right to act. That is, the right to act equally on behalf of the international community and the affected states as stated in the still-controversial Article 54 of the ILC draft articles on States' Responsibility. ${ }^{86}$ State responsibility is usually invoked to address and remedy harm and injury done by violating international obligations. However, violations of norms relating to Common Concerns may not entail direct injury to other states but rather to the international community at large. Hence, the emerging doctrine reinforces calling upon state responsibility in the case of violation of community norms and call for cessation or assurances of non-repetition in accordance with Article 48(2) of the ILC draft articles on States' Responsibility. ${ }^{87}$ Thus, injury and harm are not prerequisites to invoking state responsibility any longer. Therefore, Cottier claims that, 'Enforcing compliance will require large markets with bargaining powers to take action and exert pressures to comply. Smaller countries often

85 Cottier, 'The Principle of Common Concern of Humankind' (n 4) 68.

86 International Law Commission, 'Draft articles on responsibility of States for internationally wrongful acts' (2001) 2(2) Yearbook of the International Law Commission 26.

87 ibid. Also see James Crawford, 'State Responsibility', Max Planck Encyclopedias of Public International Law <https://opil.ouplaw.com/view/10.1093/law:epil/978019923169o/law978019923169o-e1093> accessed 21 October 2021. 
do not have the leverage, unless measures are taken jointly or within an international organization. Economic and trade sanctions are of utmost importance'. ${ }^{88}$ On this point he also recalls that 'actors taking unilateral measures are subject to the rule of law and to the principle of proportionality in shaping countermeasures'. ${ }^{89}$

Beyond the right to act under the auspices of the principle of Common Concern of Humankind, the duty to act is more controversial. While the right to act is discretional, the duty to act entails an obligation. Hence, it can be acknowledged that despite the notions of state responsibility, jus cogens and obligations erga omnes, States usually refrain from acting if they are not directly affected by the underprovision of a global public good and, eventually, a Common Concern. Hence, States tend not to assume responsibilities where there is a lack of reciprocity.

In this scenario Cottier reflects on whether the principle of Common Concern should entail a basic duty to act in order to promote and protect the areas recognised as a Common Concerns. He considers that the principle should contemplate such obligations to act in light of the existing structural weaknesses of international law. It is suggested that the principle will not trigger automatic action but must consider the principles of proportionality and accountability. If accepted, this principle of Common Concern with its duty to act 'adds a new dimension in general international law calling for a reasoned response to violations of community rights. In many instances, action will not be suitable and possible. But the mere fact that such action needs to considered and options examined renders states accountable towards the principle of Common Concern and thus enhanced compliance with international law' ${ }^{90}$

Once the normative dimensions that an eventual principle of Common Concern of Humankind may entail (with its three-dimensional elements) are clarified, it is important to consider the role that the principle will play in applying and interpreting law. In this regard, Cottier considers that once the principle is recognised in customary international law and treaty law it offers valuable guidance and informs the interpretation and application of rules on a case-by-case basis. Furthermore, he reflects that the principle informs the decisions of domestic courts in applying international law. Also, if established as a general principle of law, it may be directly applied as a matter of domestic constitutional law, informing the interpretation of legislation and regulations in various and often complex technical fields. This latter function is expected

88 Cottier, 'The Principle of Common Concern of Humankind' (n 4) 70.

89 ibid.

$90 \quad$ ibid 73 . 
to be important, as domestic courts are likely to play a relevant role in redressing the lack of reciprocity of interests identified, jointly with the influence and impact of non-state actors in the realm of domestic fora in addressing common concerns. ${ }^{91}$

Cottier also emphasises the role of non-state actors in the process of recognition of potential common concerns. The main reason for this is that states are generally reluctant to engage with issues that transcend their jurisdictions or where there is lack of reciprocity among the participants or possible free riders. For non-state actors, he refers in particular not only to political parties and non-governmental organisations, but also to business associations, multinational corporations and the media. All of these actors may have a voice and play an important role in introducing to the public whether or not an issue should be considered as a common concern and thus be dealt with within the process of claims and responses stipulated under the principle of Common Concern of Humankind. ${ }^{92}$ Also, Cottier argues that non-state actors can play a role in monitoring whether governments implement and comply with international obligations and, eventually, being entitled to file law suits in domestic courts to assess whether the homework is properly undertaken and whether the basic duty to act and to take appropriate and reasonable measures against failing states is being honoured. ${ }^{93}$

\subsection{Arguments in Support of the Principle of Common Concern of Humankind}

Finally, Cottier considers that a fully-fledged doctrine, and eventually principle, of Common Concern of Humankind will deploy long-term structural effects on international law. It will apply as a legal principle equally within all the layers of governance in order to address shared relevant problems. Cottier also recognises the objections to this doctrine based upon claims of national sovereignty and self-determination. He replies to these claims by providing six arguments that addresses main weaknesses of the doctrine and support the possible recognition of Common Concern of Humankind as a general principle of law: ${ }^{94}$

First, the principle of Common Concern of Mankind and its obligations and effects is limited to shared, serious problems. It does not apply across

\footnotetext{
91 ibid 78.

92 See Anne Peters and others (eds), Non-State Actors as Standard Setters (CUP 2009).

93 Cottier, 'The Principle of Common Concern of Humankind' (n 4) 78.

94 ibid (n 4) 87.
} 
the board. States face enhanced rights and obligations only in areas structurally perilous to peace, stability and welfare. The acceptance of the principle and its extension to particular collective action problems is subject to claims and responses and thus acceptance in treaty law or customary international law. In cannot be unilaterally imposed but is achieved due to persuasion in addressing pressing needs.

Second, the principle of Common Concern of Humankind with its obligations to cooperate, homework, compliance and duties to act addresses the lack of reciprocal interests and free-riding inherent to many collective action problems. It introduces appropriate carrots and sticks to foster mutual interests of states and communities to take up a problem, framing also the roles of non-state actors and courts of law. The costs of abstaining and free-riding exceed the benefits of cooperation.

Third, the principle of Common Concern of Humankind domestically supports governments in taking appropriate measures and in convincing electorates and overcoming populist resistance and nationalism visà-vis collective action problems at stake. Recourse to international law obligations to act and accountability structures the debate and facilitates positive outcomes.

Fourth, the principle of Common Concern of Humankind facilitates and supports the adoption of appropriate domestic policy measures. This is of great importance for large markets and powerful states and entities. The extension of extraterritorial application of domestic law pertaining to areas falling under the principle of Common Concern facilitates the adoption of measures and policies which otherwise are opposed due to impending losses of comparative advantage and competitiveness. Such incentives are of paramount importance as the resolution of main collective action problems, in particular climate change, loss of biological diversity, monetary stability, migration, human rights compliance, corporate taxation and benefit shifting (BEPS), essentially depends upon homework undertaken in large markets and how they treat imported products (goods and services) and immigration. Medium and smaller markets and countries tend to follow these policies in securing access to larger markets. It is therefore essential that the principle of Common Concern of Mankind primarily facilitates action by large markets and powerful states in addressing collective action problems. 
Fifth, the principle of Common Concern of Humankind does not leave medium and small states powerless once they have agreed to treat a problem under its umbrella. They can form flexible coalitions in supporting the principle and its application of severe problems. They can develop initiatives on the international level at cooperation and harmonization of standards and rules. They can shape appropriate procedures of participation and decision-making in international organizations by adopting majority rulings. They can offset passivity and even resistance by large markets and powers and develop joint leadership under the principle of Common Concern of Humankind.

Sixth, the principle of Common Concern of Humankind is subject to judicial control in international courts and arbitration. Measures taken and having extraterritorial effect, as well as countermeasures and sanctions imposed are subject to the principle of proportionality. They need to pass a necessity test. Should countries, in particular large markets, adopt measures not suitable to address the collective action problem in a conducive manner, such measures can be challenged in court and are subject to single or collective countermeasures.

Monetary Stability as a Common Concern of Humankind A Preliminary Assessment

The current state of affairs of the international monetary system (IMS) together with the problems highlighted by the GFC make a strong case for the consideration of international monetary stability as a Common Concern. As highlighted in chapter 1, the GFC evidenced two central loopholes in the current structure of the IMS: the lack of appropriate global institutions and the lack of adequate international cooperation. Despite the efforts of the international community to tackle these global issues, as the chapter pointed out, the role of public international law in monetary affairs has reached its limits and thus a reconsideration of the role of the states in the pursuit of international monetary stability, through their monetary authorities, is required. In this context, chapter 2 acknowledged that monetary stability, while being an indisputable sovereignty issue, also has an international dimension. Therefore, it is claimed that there is a clear trade-off among the stability objectives at the different levels of governance of the international monetary order. The outcome of this trade-off is the preference of the stability of the domestic and regional orders to the stability of the whole international monetary order. 
On this imbalance among international stability, globalisation (or global governance) and national sovereignty, Dani Rodrik in his influential work proposes a return to nation states and national sovereignty as a strong critique on the failures of global governance. Rodrik considers that there is a 'political trilemma of the world economy' by arguing that it is impossible to have at the same time: hyper-globalization (deep economic integration), nation state (national sovereignty) and democratic politics. He considers that we can have at most two out of three. Hence, since democracy cannot be conceded, Rodrik proposes a return to nation states. ${ }^{95} \mathrm{He}$ reflects that 'global standards and regulations are not just impractical; they are undesirable. The democratic legitimacy constraint ensures that global governance will result in the lowest common denominator, a regime of weak and ineffectual rules. ${ }^{96}$ On the contrary, this book argues elsewhere that the answer to the dichotomy among national laws and global markets is more international laws and international institutions to govern global markets. Indeed, underprovided GP G s, such as international monetary stability, demand enhanced international rules.

Consequently, it can be argued that the process of claims and responses for an issue to amount to a Common Concern, as proposed by the Common Concern doctrine, is a valuable methodological approach to evaluate the problems associated with the provision of monetary stability from a multilevel governance perspective. In order to start the process of claims and responses the threshold of threat to peace, stability and welfare must be fulfilled. In the context of this book, an unstable international monetary system can lead to unrest and breakdowns. This is illustrated by the historical example of the inter-war period, during which the economic breakdown in the Great Depression contributed to the breakdown of international peace and stability. As very clearly remarked by Lastra, the maintenance and promotion of peace, stability and welfare is enshrined in the very foundations of the IMF:

Drawing on the lessons of history, it was in the context of World War II that countries were ready to make the sacrifices needed in terms of sovereignty by signing a number of international treaties that gave rise to international organizations such as the United Nations, the International Monetary Fund (IMF), and the World Bank. John Maynard Keynes had wisely stated that in order to win the war we needed to 'win the peace'. It was this understanding that also inspired Henry Morgenthau (then US

\footnotetext{
95 Dani Rodrik, The Globalization Paradox: Democracy and the Future of the World Economy (WW Norton \& Company 2011) 200. 
Treasury Secretary) to proclaim in the opening remarks of the Bretton Woods conference in New Hampshire in July 1944 that 'prosperity like peace is indivisible'. Neither Keynes nor Morgenthau were thinking only in territorial/national terms: they were thinking in international terms. ${ }^{97}$

Having reached the threshold for the consideration of international monetary stability as a matter of Common Concern the process of claims and responses should be analysed from a three-dimensional perspective. As described above, it starts with the duty to cooperate, consult and negotiate, continuing with the basis for obligations at home and ending with securing compliance with the obligations that may emerge from the Common Concern of monetary stability. The following three chapters of this book are devoted to the study and analysis of these three dimensions in order to provide an assessment on whether international monetary stability amounts to a Common Concern of Humankind.

Firstly, the emerging doctrine of Common Concern aims to enhance and strengthen the duty to cooperate internationally as the best solution to solve the problems associated with Common Concerns. As remarked elsewhere in this book, international cooperation for the pursuit of monetary stability has experienced different periods, from a rule-based and multilateral system during the Bretton Woods period to the bilateral, regional and soft-law based system that we have at present. The powers conferred on the IMF concerning the pursuit of global stability have been limited since the Second Amendment to the Articles of Agreement of the IMF (the Second Amendment). The GFC showed that central banking cooperation works well in a crisis, but its efficacy diminishes when the crisis starts to calm down and independent and uncoordinated responses flourish everywhere.

Consequently, Common Concern, if established as a principle, aims to enhance the duty to cooperate in monetary affairs both from a top-down approach and a bottom-up approach. While the top-down approach relates to the duty to cooperate at the international level of governance with the IMF as the central international monetary institution, the bottom-up approach considers cross-border cooperation among countries with a special emphasis on monetary policy coordination among central banks. This first dimension is examined in detail in chapter 4 . The chapter starts by providing an analysis of the top-down approach with a focus on the key role played by the IMF at the international level of governance and an examination of the core elements of 
the IMS. It continues with a study of the bottom-up approach giving emphasis to the cases of central banking cooperation.

Secondly, the emerging doctrine of Common Concern promotes the obligations to do homework with two levels of commitment: the duty to promote and protect the Common Concern at the local level and the duty to implement international commitments assumed in international agreements and in customary law. For the first level of commitment, the pursuit and maintenance of monetary stability as a domestic public good and a local Common Concern is a clear sovereignty attribute and a state defines what is to be considered as monetary stability locally. The pursuit of monetary stability is usually entrusted to an independent central bank or the relevant monetary authority. For the second level of commitment, states shall comply with international commitments assumed in international agreements and in customary law.

As detailed elsewhere in this book, since the modifications introduced by the Second Amendment the limits set by international public law on the monetary sovereignty powers of the states are general, non-specific and of a soft-law nature. In consequence, the emerging doctrine aims to encourage autonomous domestic policymaking to cope with the underlying issues related to the Common Concern. That is, to reinforce the role of states as main providers of GPGs not only locally but also globally. In monetary affairs, unilateral actions with extraterritorial effects have proved useful in the pursuit of monetary stability but are limited and temporary in nature. This second dimension of the doctrine is studied in deep in chapters 5 and 6. While chapter 5 deals with the special role of central banks (or relevant monetary authority) as the guardians of monetary stability locally, chapter 6 considers domestic unilateral actions with extraterritorial effects regarding monetary affairs.

Thirdly, the last element of the emerging doctrine of Common Concern relates to securing compliance with the obligations that may emerge from the doctrine and eventually principle of Common Concern. These obligations, as laid out in the doctrine of Common Concern, entail an enhanced duty to cooperate globally and the obligations to do homework both within the local jurisdiction and across borders when needed through unilateral lawful measures. As presented elsewhere in this book, the lack of effectiveness of the existing mechanisms of international law to secure compliance with the obligations concerning global monetary stability bring back to the debate the trade-off among the different levels of governance in monetary affairs. This delicate debate about compliance is studied in chapter 6 of this book. 
The most recent global financial crisis, the GFC, exposed both market and governance failures in the provision and protection of G P G s such as global financial and monetary stability. The market imperfections uncovered the governance failures at the different levels of governance with inadequate domestic regulatory frameworks to internalise negative externalities and also the absence of an appropriate international regulatory framework. As remarked by Shaffer, 'Globalization pressures transform issues that formerly were national in scope into global ones. With globalization, national decision-making increasingly has externalities on outsiders, and it is increasingly insufficient to attain national goals. International law and institutions thus rise in importance. ${ }^{98}$

This chapter argues that the underprovision of GPG s, in particular international monetary stability, demands a collective action response with increased international cooperation among the different levels in the multilevel governance structure. It also contends that international public law and institutions are fundamental to overcoming collective action problems. However, formal and enforceable international public law in monetary affairs seems to have reached its limits. ${ }^{99}$ Consequently, this chapter claims that the emerging doctrine of Common Concern of Humankind offers some valuable guidance and directions for the issues pointed out in this specific case study on global monetary stability. As defined by Cottier:

Common Concern of Humankind, as a source of inspiration, direction and eventually a legal principle of international law recognised by the international community deploys significant long-term structural effect on international law. It will move it from co-existence and cooperation to integration in the long run. In reality, this blueprint is likely to materialise piece-meal in a gradual process of claims and responses, trial and error. In the long run, it will develop and foster a new understanding of sovereignty of states and the realization of multi-level governance with

98 Gregory Shaffer, 'International Law and Global Public Goods in a Legal Pluralist World' (2012) 23(3) EJIL 692.

99 Petersmann argues that 'ineffective protection of public goods is mainly due to a lack of adequate theories, rules, and institutions for overcoming the collective action problems in multilevel governance of interdependent public goods'. Petersmann, 'International Economic Law, "Public Reason", and Multilevel Governance of Interdependent Public Goods' (n 1 ) 23 . 
a view to produce appropriate public goods on appropriate levels of governance. ${ }^{100}$

Accordingly and despite the fact that, at the moment, a reform of the legal and institutional arrangements concerning monetary affairs at the international level with the new obligation to act proposed by Common Concern seems unrealistic, this book aims to be a source of debate and inspiration for academics and policymakers alike in the path to achieve a more prosperous and stable international monetary system with the guidance of the emerging doctrine of Common Concern of Humankind.

100 Cottier, 'The Principle of Common Concern of Humankind' (n 4) 84. 